why some authors have found these factors to be associated with jaundice ${ }^{2}+58$ while others have not. ${ }^{910}$

The mechanism of the icterogenic effect of these drug treatments is obscure. Neither bupivacaine, the local anaesthetic used in epidural blocks, nor oxytocin has any direct effect on glucuronidation of bilirubin in vitro. ${ }^{11}$ The hypo-osmotic effect of oxytocin has been implicated, ${ }^{12}$ as has the increased placental transfusion of fetal blood resulting from oxytocin. ${ }^{13}$ So far as oxytocin induction is concerned this relationship may be due to an association between the use of induction in chronologically mature but physiologically immature infants who fail to initiate parturition.

The finding that premature, small-for-dates infants were protected from jaundice by their low weight suggests that hepatic glucuronyl transferase is prematurely developed in small-fordates infants. This development recalls the accelerated surfactant production by the lung in small-for-dates infants, which has been attributed to intrauterine stress. ${ }^{14}$ A teleological explanation would be that early maturation of liver and lung enzymes may prepare small-for-dates infants for premature delivery.

Neonatal jaundice is undoubtedly a time-consuming clinical problem. Severe physiological jaundice is associated with mild brain damage, ${ }^{1516}$ although classical kernicterus is rare. Our results indicate that the problem is unlikely to be resolved by changes in obstetric practice, for even elimination of epidural anaesthesia and oxytocin use would have little impact. These considerations may suggest to paediatricians that they should look again at prophylactic prenatal drug treatment for neonatal jaundice. Though phenobarbitone is effective, ${ }^{6}$ its adverse effects may be greater than the morbidity and medical costs of a significant rate of neonatal jaundice; other enzyme-inducing agents might be found with fewer side effects.

We are grateful to Miss E C Curtis, Queen Charlotte's Hospital, and the computing advisory service, London School of Hygiene and Tropical Medicine. This study was supported by the Wellcome Trust.

\section{References}

1 Scheidt, P C, et al, fournal of Pediatrics, 1977, 91, 292.

2 Sims, D G, and Neligan, C A, British fournal of Obstetrics and Gynaecology, $1975,82,863$

${ }^{3}$ Campbell, N, Harvey, D, and Norman, A P, British Medical fournal, $1975,2,548$.

${ }^{4}$ Davies, D P, et al, British Medical fournal, 1973, 3, 476.

5 Beazley, J M, and Alderman, B, British fournal of Obstetrics and Gynaecology, 1975, 82, 265.

6 Trolle, D, Lancet, 1968, 2, 705.

Friedman, L, Lewis, P, and Harvey, D, British Medical fournal, 1977, 2, 1223.

${ }^{8}$ Chew, W C, and Swann, I L, British Medical fournal, 1977, 1, 72.

${ }^{9}$ Friedman, E A, and Sachtleben, M R, British Medical fournal, 1976, 1, 198.

10 Boylan, P, British Medical fournal, 1976, 2, 564.

${ }^{11}$ Lewis, P J, Therapeutic Problems in Pregnancy, p 141. Lancaster, Medical and Technical Publishing, 1977.

${ }^{12}$ Singhi, S, and Singh, M, British Medical fournal, 1977, 2, 1028.

${ }_{13}$ Gate, J M, British Medical fournal, 1978, 1, 49.

${ }^{14}$ Gluck, L, and Kulovich, M V, American fournal of Obstetrics and Gynecology, 1973, 115, 539.

${ }^{15}$ Boggs, T R, jun, Hardy, J B, and Frazier, T M, fournal of Pediatrics, $1967,71,553$.

${ }^{16}$ Fenwick, J D, fournal of Laryngology and Otology, 1975, 89, 925.

(Accepted 27 February 1978)

\title{
High prevalence of hyperuricaemia and gout in an urbanised Micronesian population
}

\author{
P Z ZIMMET, S WHITEHOUSE, L JACKSON, K THOMA
}

British Medical Fournal, 1978, 1, 1237-1239

\section{Summary and conclusions}

The prevalence of hyperuricaemia and gout was investigated in the Micronesian inhabitants of the highly urbanised central Pacific island of Nauru. Sixty-four per cent of men and $60 \%$ of women aged 20 years and over had hyperuricaemia - the highest prevalence rates yet reported for a population. The hyperuricaemia in men was accompanied by a high prevalence of clinical gout $(6.9 \%)$.

While the hyperuricaemia is probably genetic, the high prevalence of gout may be related to the environmental change from the traditional island style of living to one of almost complete Westernisation.

\footnotetext{
Department of Metabolic Medicine and Epidemiology, Southern Memorial Hospital, Melbourne 3162, Australia

P Z ZIMMET, PHD, FRACP, director

$S$ WHITEHOUSE, computer fellow

L JACKSON, MB, BS, research associate

$\mathrm{K}$ THOMA, DMs, director of medical services, Nauru
}

\section{Introduction}

As the Third World nations change from subsistence to cash economies, drastic changes have occurred in the social, cultural, and health aspects of their societies. With the shedding of the traditional lifestyle for the seemingly more glamorous Western style of living and eating, there has been a dramatic rise in the prevalence of chronic degenerative diseases such as diabetes mellitus, hypertension, heart disease, and gout-conditions previously unknown or rare in these populations. ${ }^{1-4}$ Nowhere have these changes been more apparent than in the developing countries of the Pacific.

Nevertheless, while diabetes, hypertension, and heart disease are rare in populations maintaining traditional lifestyles and appear only in their urbanised counterparts, ${ }^{5}$ hyperuricaemia has been reported in Pacific islanders both affected and unaffected by Western influences. ${ }^{1}$ Thus, while the clinical expression of hyperuricaemia may be influenced by the change to a modern lifestyle, the actual metabolic abnormality is present in both environments.

In one particular Micronesian population the results of Western influence have been disastrous. In a recent survey of the population of the urbanised central Pacific island of Nauru we found that $34.4 \%$ of the people aged 15 years and over had diabetes. ${ }^{3}$ This figure is comparable with that of the American Pima Indians-a population with the highest prevalence of diabetes ever reported. 
In view of the earlier reports on the presence of hyperuricaemia in Polynesian and Micronesian societies, ${ }^{1}{ }^{7}$ we investigated the problem in the Nauruan population. We report here on the prevalence of hyperuricaemia and clinical gout in this urbanised Micronesian population.

\section{Subjects and methods}

Nauru is situated in the central Pacific at longitude $16055^{\prime}$ east and latitude $0^{\circ} 32^{\prime}, 37$ miles south of the equator. It is one of the most isolated islands in the Pacific Ocean, being 1600 miles from Honolulu and 2500 miles from Sydney. It is also the smallest and richest republic in the world, the per caput income being about \$US30 000 per annum. The republic's phosphate industry (controlled by the British Phosphate Commission until 1969) is the reason for the country's wealth. The lifestyle of the Nauruans is completely Westernised and, as the soil is infertile, almost all food is imported from Australia. Obesity is a feature of the adult population.:

Details of the survey population and its selection have been reported elsewhere ${ }^{3}{ }^{8}$; the subjects tested were representative of the Nauruan population. Fasting venous blood was drawn from 455 subjects (217 men and 238 women) aged 20 years and over, who represented onethird of the island's population in this age group. Serum urate concentrations were measured on the SMAC 20 (Technicon Instrument Corporation) using a colorimetric method. ${ }^{9}$

The results were analysed using Student's $t$ test for unpaired variates. The criterion of significance was a $P$ value $<0.05$.

Criteria for hyperuricaemia-Men with a serum urate concentration

$\geqslant 0.42 \mathrm{mmol} / 1(7 \mathrm{mg} / 100 \mathrm{ml})$ and women with a concentration $\geqslant 0.36 \mathrm{mmol} / 1(6 \mathrm{mg} / 100 \mathrm{ml})$ were classified as hyperuricaemic. These criteria conformed to those of Kellgren et al. ${ }^{10}$

Clinical gout-The criteria chosen for clinical gout were those used by Prior $e t$ al $l^{1}$-that is, a history of typical podogra affecting the joints of the great toe or foot. The subjects were interviewed by two members of the medical team, and a local nurse acted as an interpreter when necessary. The urate concentrations were not known when the history was taken. Cases were defined as definite when this history was combined with a serum urate concentration $\geqslant 0.42 \mathrm{mmol} / 1(7 \mathrm{mg} / 100 \mathrm{ml})$ in men and $0.36 \mathrm{mmol} / 1(6 \mathrm{mg} / 100 \mathrm{ml})$ in women.

\section{Results}

The mean serum urate concentrations for Nauruan women and men are shown in table I. Concentrations tended to increase with age in women and fall with age in men. The mean concentrations were

TABLE I-Mean serum urate concentrations (mmol/l) in Nauruan men and women

\begin{tabular}{|c|c|c|c|c|c|c|}
\hline \multirow{2}{*}{\multicolumn{3}{|c|}{$\begin{array}{c}\text { Age } \\
\text { distribution } \\
\text { (years) }\end{array}$}} & \multicolumn{2}{|c|}{ Men } & \multicolumn{2}{|c|}{ Women } \\
\hline & & & \multirow{2}{*}{$\begin{array}{l}\text { No } \\
74 \\
44 \\
53 \\
28 \\
18\end{array}$} & \multirow{2}{*}{$\begin{array}{c:c}\text { Mean }: \text { SD } \\
0.47: 0.07 \\
0.45: 0.11 \\
0.43: 0 \cdot 10 \\
0.40: 0.09 \\
0.44: 0.12\end{array}$} & \multirow{2}{*}{$\begin{array}{l}\text { No } \\
96 \\
46 \\
45 \\
37 \\
14\end{array}$} & \multirow{2}{*}{\begin{tabular}{c:c} 
Mean $:$ SD \\
\hdashline $0.37: 0.08$ \\
$0.36: 0.06$ \\
$0.38: 0.08$ \\
$0.39: 0.09$ \\
$0.39: 0.06$
\end{tabular}} \\
\hline $\begin{array}{c}20-29 \\
30-39 \\
40-49 \\
50-59 \\
60\end{array}$ & $\begin{array}{l}\ldots \\
\cdots \\
\cdots\end{array}$ & $\begin{array}{l}\ldots \\
\ldots \\
\ldots \\
\ldots\end{array}$ & & & & \\
\hline All ages & s.. & .. & 217 & $0 \cdot 45 \pm 0 \cdot 10$ & 238 & $0.38 \pm 0.08$ \\
\hline
\end{tabular}

Conversion: SI to traditional units-Urate: $1 \mathrm{mmol} / 1=16 \cdot 8 \mathrm{mg} / 100 \mathrm{ml}$.
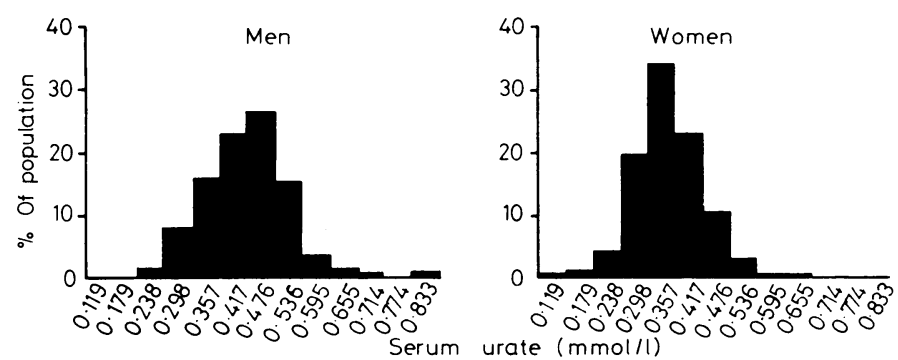

Frequency distributions of serum urate concentrations in Nauruan men and women. higher in men in all age groups, and, except among Nauruans aged 50 and over, the differences were statistically significant.

The frequency distribution of serum urate concentrations in men and women are shown in the figure. In both groups the distributions were clearly unimodal, and the mean serum urate concentration was $0.45 \mathrm{mmol} / 1(7.5 \mathrm{mg} / 100 \mathrm{ml})$ in men and $0.37 \mathrm{mmol} / 1(6.2 \mathrm{mg} / 100 \mathrm{ml})$ in women.

Table II shows the number and percentage of men and women with hyperuricaemia and with clinical gout.

TABLE II-Prevalence of hyperuricaemia and gout in Nauruan men and women

\begin{tabular}{|c|c|c|c|c|}
\hline & & No & $\begin{array}{c}\text { No }\left("{ }^{\prime \prime}\right) \text { with } \\
\text { hyperuricaemia* }\end{array}$ & $\begin{array}{c}\text { No (" }{ }^{\prime \prime)} \text { with } \\
\text { gout }\end{array}$ \\
\hline $\begin{array}{l}\text { Men .. } \\
\text { Women }\end{array}$ & $\begin{array}{l}\ldots \\
\ldots\end{array}$ & $\begin{array}{l}217 \\
238\end{array}$ & $\begin{array}{l}138(63 \cdot 6) \\
143(60.0)\end{array}$ & $\begin{array}{r}15(6.9) \\
1(0.4)\end{array}$ \\
\hline
\end{tabular}

\section{Discussion}

Our results indicate that Nauruan men and women have the highest prevalences of hyperuricaemia yet reported in a population $-64^{\circ}$, and $60^{\circ}$, respectively. The prevalence of clinical gout was extremely high in men $\left(6.9^{\circ}{ }_{0}\right)$ and comparable with the $2 \cdot 4^{\circ}$, to $10 \cdot 2^{\circ}$ o rates found in the Polynesian populations studied by Prior et al. ${ }^{1}$

The highest prevalence of hyperuricaemia that Prior et al found occurred among Pukapukan men $\left(48 \cdot 5_{0}^{\circ}\right)$ and women $(49 \%)$. These workers suggested that there was a strong genetic predisposition to hyperuricaemia because the extent of the problem in the three Polynesian groups studied (New Zealand Maoris, Raratongans, and Pukapukans) was remarkably similar despite great differences in their environments. The high rates found among the Polynesians contrasted with a prevalence of hyperuricaemia among New Zealand Caucasians of $23 \%$ in men and $16^{\circ}$ o in women. Among this Caucasian population $2 \%$ of men and $0.4 \%$ of women had gout.

Further evidence that hyperuricaemia is genetically determined and unrelated to the extent of environmental change comes from studies in the American Pima Indians. This urbanised population has an extremely high prevalence of diabetes, comparable with that of the Nauruans, ${ }^{6}$ but their mean serum urate concentrations are about half those of the Nauruans, and much lower than those of American Caucasians. The prevalence of hyperuricaemia in Pima Indians aged 30 years and over is $3 \cdot 3^{\prime \prime} .^{11}$

Serum urate concentrations had a unimodal distribution in Nauruan men and women, which were consistent with the distributions reported in Caucasian ${ }^{12}$ and Pacific populations. ${ }^{1}$ This suggests that the hyperuricaemia in Nauru is not due to a single genetic trait but conforms to a pattern of genetic polymorphism.

There was definite family grouping of gouty subjects in Nauru and this genetic component has also been noted for diabetes in this population. ${ }^{3}$ Considerable intermarriage has occurred in the island community because of its extreme isolation. Thus any genetic trait such as gout or diabetes would be amplified, and this might explain the high prevalence of both of these diseases in this community.

Prior et al noted a higher attack rate of gout among the more urbanised Polynesians whom they studied. ${ }^{1}$ They suggested that environmental factors might influence the precipitation of clinical episodes in subjects with a genetic predisposition. In the partly urbanised Polynesian population of Funafuti, Tuvalu (formerly Ellice Islands), we found that $32^{\circ} \circ$ of men and $35^{\circ}$ \% of women had hyperuricaemia, ${ }^{13}$ but we found no cases of clinical gout. Our findings in Nauru and Tuvalu therefore support the contention that, while the hyperuricaemia has a genetic basis, clinical gout is probably caused by the dramatic environmental change from a traditional to a Western lifestyle. The increased wealth, a high-energy, highly refined carbo- 
hydrate diet, reduced physical activity, and obesity may be the important factors implicated. And all these factors seem to operate in the Nauruan population. ${ }^{8}$

This work was supported in part by a grant from the National Health and Medical Research Council of Australia. We thank the government of the Republic of Nauru for allowing the study to proceed, and Miss Roma Swan for typing the manuscript.

\section{References}

${ }^{1}$ Prior, I A M, et al, Lancet, 1966, 1, 333

2 West, K M, Diabetes, 1974, 23, 841.

${ }^{3}$ Zimmet, P, et al, Diabetologia, 1977, 13, 111

${ }^{4}$ DeBoer, W, Collins, J, and Zimmet, P, Diabetologia, 1977, 13, 388
5 Prior, I A M, and Davidson, F, New Zealand Fournal of Medicine, 1966, 65, 375.

Bennett, P H, Burch, T A, and Miller, M, Lancet, 1971, 2, 125.

7 Reed, D, Labarthe, D, and Stallones, R, Arthritis and Rheumatism, 1972, 15,381 .

${ }^{8}$ Zimmet, P, Arblaster, M, and Thoma, K, Australian and New Zealand Fournal of Medicine. In press.

${ }^{9}$ Sobrinho-Simoes, M, fournal of Laboratory and Clinical Medicine, 1965, $65,665$.

${ }^{10}$ Kellgren, J H, Annals of the Rheumatic Diseases, 1964, 23, 109.

${ }_{11}$ O'Brien, W M, Burch, T A, and Bunim, J J, Annals of the Rheumatic Diseases, 1966, 25, 117.

${ }^{12}$ Mikkelsen, W M, Dodge, H J, and Valkenburg, H, American fournal of Medicine, 1965, 39, 242.

${ }^{13}$ Collins, J, et al, Proceedings of the 6th Asia and Oceania Congress of Endocrinology, Singapore, 1978. In press.

(Accepted 22 February 1978

\title{
Mechanism of action of insulin in diabetic patients : a dose-related effect on glucose production and utilisation
}

\author{
P M BROWN, C V TOMPKINS, S JUUL, P H SÖNKSEN
}

British Medical fournal, 1978, 1, 1239-1242

\section{Summary and conclusions}

Six insulin-requiring diabetics were studied after insulin had been withheld for 24 hours. On three separate occasions each received a two-hour infusion of insulin at a low dose $(2.6 \mathrm{U} / \mathrm{h})$ and a high dose $(10.6 \mathrm{U} / \mathrm{h})$ and an infusion of saline as control. The rates of production and utilisation of glucose were measured isotopically. The rate of fall of plasma glucose concentration was faster on the high-dose infusion of insulin than on the low, whereas the fall in plasma free fatty acids, glycerol, and keton bodies was the same on both insulin infusions. The mechanism whereby the two rates of insulin administration lowered plasma glucose concentration differed: during the low-dose infusion the decrease in the glucose concentration was produced entirely by a fall of hepatic glucose output, whereas during the high-dose insulin infusion the glucose concentration fell because both the rate of glucose production fell and the rate of glucose utilisation rose. In all experiments there was a direct relation between a fall in serum potassium concentration and the fall in plasma glucose concentration irrespective of the mechanism that reduced the glucose concentration.

These results indicate that in uncontrolled diabetics low-dose insulin infusions lower the blood glucose concentration entirely by reducing glucose production from the liver and that the effect of insulin on potassium transport is independent of its effect on glucose uptake.

\section{Introduction}

With the recent development of low-dose insulin infusions for treating diabetic ketoacidosis ${ }^{12}$ we wondered whether insulin

Department of Medicine, St Thomas's Hospital Medical School, London SE1 7EH

P M BROWN, MRCP, research fellow

C V TOMPKINS, PHD, assistant lecturer

S JUUL, MSC, research assistant

$P$ H SÖNKSEN, FRCP, reader in medicine lowered blood glucose concentration by increasing glucose uptake by peripheral fat and muscle tissues or by reducing glucose production. Most studies that have shown an effect of insulin on increasing glucose transport into muscle have used high concentrations of insulin outside the physiological range. ${ }^{34}$ The effect of insulin in reducing hepatic glucose output was emphasised in the past ${ }^{5-;}$ but has been largely ignored recently. We used an isotope-turnover technique to measure the rates of production and utilisation of glucose during different rates of insulin infusion in hyperglycaemic diabetics treated with insulin. The rates of insulin infusion were chosen to produce plasma insulin concentrations in the low and high physiological range. ${ }^{*}$

A fall in blood glucose concentration is known to be associated with a fall in serum potassium concentration and we therefore also studied changes in serum potassium during the insulin infusions.

\section{Patients and methods}

\section{PATIENT SELECTION AND PREPARATION}

Six insulin-dependent diabetic men aged 26 to 61 years were recruited from our diabetic clinic. The nature of the investigations was explained and their written consent to participate was obtained. Their diabetes had been treated with various types of short- and medium-acting insulin for a mean of 15.2 years (range 1.5-37). Their mean daily insulin requirement was 63 units (range 44-84). All were within $10 \%$ of ideal body weight. ${ }^{9}$

Each patient was studied on three separate occasions, at least one week apart. They received in random order either $(a)$ a low-dose $(2.6 \mathrm{U} / \mathrm{h})$ or $(b)$ a high-dose $(10.6 \mathrm{U} / \mathrm{h})$ infusion of monocomponent porcine insulin or (c) normal saline as placebo. Each patient, therefore, acted as his own control. Patients were studied as outpatients on the morning after an overnight fast. An appropriate dose of Actrapid monocomponent insulin (Novo) was substituted for the patients' usual insulin 24 hours before each study and insulin treatment was then withheld.

EXPERIMENTAL PROTOCOL

Cannulae were inserted into the antecubital veins of both arms using $1 \%$ procaine as local anaesthetic. One cannula was used for blood sampling and the other for infusions. An appropriate priming 